JURNAL RUPA VOL 4 NO 1 JUNE 2019

DOI address: http://doi.org/10.25124/rupa.v\%vi\%i.2249

\title{
Studi Preferensi Masyarakat Jakarta Terhadap Genderless Fashion
}

\author{
Nadiah Salsabila Hakim Pambudi $1^{*}$, Achmad Haldani2, G Prasetyo \\ Adhitama3 \\ 1,2,3 Fakultas Seni Rupa dan Desain, Institut Teknologi Bandung
}

\begin{abstract}
The evolution of clothing style always repetitive, one of them is genderless fashion. In Indonesia, especially in Jakarta, genderless clothing is not exposed too much to the public. This research aims to find the meaning of genderless fashion which often indentify as androgyne fashion and people's preference for genderless fashion. This research collects data through a literature review as well as using questionnaires to find out the preferences of the Jakarta people towards genderless fashion. According to data analysis, it can be interpreted that genderless fashion is a designing process for clothing without any specific gender orientation. The difference lies in one's physical character, the concept of androgyne fashion is for individuals who has male and female characteristic. The results of questionnaires regarding the preferences are most people know the meaning of genderless fashion and this phenomenon can be accepted in society. However, there are limits that cannot be accepted yet, such as clothes with feminine silhouette and very bright colors. This research intended to be able to rectify public confusion over understanding genderless fashion and androgyne fashion as well as a source of knowledge for designer who wants to know the limitation and acceptence rate for genderless fashion in Jakarta.
\end{abstract}

Keywords: androgyne fashion, genderless fashion, Jakarta society, preference

$\begin{array}{ll}\text { *Nadiah Salsabila Hakim Pambudi } \\ \text { Email } & \text { : nadiahpambudi@gmail.com } \\ \text { Address } & \text { : Fakultas Seni Rupa dan Desain, Institut Teknologi Bandung } \\ & \text { Jalan Ganesha no.10 Bandung } 40116\end{array}$




\title{
Studi Preferensi Masyarakat Jakarta Terhadap Genderless Fashion
}

\author{
Nadiah Salsabila Hakim Pambudi, Achmad Haldani, G Prasetyo Adhitama
}

\section{PENDAHULUAN}

Pembuatan bahan untuk pakaian di zaman sekarang tidak sesulit pada zaman purba. Pakaian pertama yang pernah ada terbuat dari kulit dan bulu binatang, daun-daunan dan rumput, serta tulang. Menurut Haldani [1] sejarah perkembangan busana menunjukkan bahwa pembedaan jenis busana berdasarkan jenis kelamin dianggap tidak selamanya benar. Pakaian pria di Yunani, Romawi atau pakaian tradisional Skotlandia, mirip sekali dengan potongan rok atau skirt. Di belahan Timur jauh dan Timur dekat, kaum wanitanya justru memakai celana panjang atau trousers. Di Mesir baik wanita maupun pria samasama menggunakan busana sejenis rok. Perbedaan mereka hanyalah dalam hal perbedaan panjangnya, dimana rok pria lebih pendek dari rok wanitanya. Dilihat dari pernyataan di atas dapat disimpulkan bahwa, di zaman dahulu kategori pakaian seperti rok dan celana adalah pakaian yang dapat digunakan untuk pria dan wanita. Tidak seperti sekarang, pakaian seperti rok selalu dikaitkan dengan wanita dan pakaian seperti celana dikaitkan dengan pria. Mulai dari tahun 2000-an, muncul kategori gaya berpakaian yang lebih spesifik yaitu genderless fashion.

Pakaian adalah salah satu penanda kelas dan gender yang paling terlihat sehingga berguna dalam mempertahankan atau menumbangkan batas simbolik dalam masyarakat [2]. Genderless fashion sering dikaitkan dan disamakan dengan androgynous fashion, secara sekilas dua hal tersebut terlihat sama karena konsep fashion mereka yang sama, yaitu pakaian untuk semua gender, pria maupun wanita. Dalam hal identitas gender, androgynous adalah orang yang tidak masuk dalam kriteria maskulin versus feminin [2].

Busana yang berbau genderless atau unisex dan digunakan oleh pria sering digolongkan ke kategori satu kelompok spesifik yaitu kaum LGBTQ+. Hal ini disebabkan oleh persepsi masyarakat yang menganggap jika seseorang mengenakan pakaian seperti wanita maka seseorang itu adalah penyuka sesama jenis atau yang disebut gay. Menurut glaad.org LGBTQ adalah akronim dari lesbian, gay, bisexual, transgender, dan queer. Dengan mulai terbukanya berbagai identitas gender di masa sekarang, kebutuhan pakaian menjadi lebih spesifik dan tidak hanya dikategorikan sebagai pakaian wanita saja atau pria saja melainkan identitas gender yang lain. Seperti adanya pakaian genderless atau yang biasanya disebut unisex.

Tren pakaian genderless sudah banyak digeluti oleh desainer luar negeri seperti Rad Hourani, Rick Owens, Neil Barrett dan juga J. W Anderson. Pakaian secara kreatif digambarkan sebagai kulit kedua [3] maka dari itu kebutuhan yang bersifat spesifik dan preferensi masyarakat atas gaya tertentu ini dapat menjadi pasar baru bagi para desainer, dimana gaya tersebut belum terlalu dieksplor oleh para desainer terutama di Indonesia. Penelitian ini diharapkan dapat memperjelas apa arti sebernarnya dari genderless fashion dan perbedaannya dengan androgyne fashion, dimana masyarakat mempunyai persepsi bahwa dua kategori fashion tersebut adalah hal yang sama dan mencari tahu bagaimana persepsi masyarakat Indonesia terhadap genderless fashion yang mulai berkembang.

Genderless atau unisex fashion adalah fenomena yang sudah lama terjadi dan mulai terlihat kembali, tetapi kebanyakan masyarakat mengetahuinya sebagai sesuatu yang sama dengan istilah androgyne, genderless fashion adalah sesuatu yang tidak memiliki gender dan bersifat netral. Genderless fashion adalah cara berpakaian yang sangat spesifik dan para desainer mulai membuat rancangan yang mangacu kepada genderless fashion. 
Sedangkan androgyne fashion dapat didefinisikan sebagai individu yang menggabungkan unsur feminin dan maskulin di dalam tubuh mereka, dimana mereka juga mempunyai kualitas sebagai feminin dan maskulin [4]. Melihat perkembangan fashion yang terjadi di Indonesia bukanlah hal yang sulit, dengan adanya media sosial masyarakat dengan mudah dapat mengakses perkembangan atau tren fashion yang sedang terjadi. Banyak bermunculannya konsep berpakaian genderless di media membuat pertanyaan apakah genderless fashion dapat diterima di masyarakat atau tidak dan bagaimana preferensi masyarakat atas hal tersebut.

\section{Genderless Fashion di indonesia}

Menurut Haldani, perkembangan teknologi dan penggunaan media sosial dalam keseharian setiap individu merupakan salah satu cara yang mudah untuk melihat perkembangan fashion di Jakarta [1]. Pada dasarnya pengaruh pakaian dari masa lalu akan terus berulang dan menginspirasi dunia fashion dari masa ke masa. Begitu juga tren fashion di Indonesia terutama di kota besar seperti Jakarta yang sering dipengaruhi oleh tren Barat. Tren berpakaian di Indonesia dipengaruhi oleh musik, film dan juga media sosial. Munculnya Elvis Presley pada tahun 1950-an membuat gaya Glam muncul di Indonesia. Pada tahun 1960-an hingga awal 1970-an tren seperti pakaian berupa kemeja satin ketat, rambut panjang, penggunaan maskara bagi pria dan sepatu dengan model hak tinggi. Sementara wanita pada masa itu menggunakan pakaian layaknya pria, seperti celana panjang lurus ketat dan tidak menggunakan riasan wajah. Pada tahun 1990-an hingga 1995-an muncul gaya Skaters diikuti dengan gaya Grunge melalui band musik seperti Nirvana dengan pakaian berupa telanjang dada. kemeja longgar, overall tanpa di kancing, rambut panjang di kepang dan memakai anting. Pada awal tahun 2000-an gaya berpakaian Emo mulai muncul dengan pengaruh penyanyi seperti Avril Lavigne dan My Chemical Romance yang menggunakan eyeshadow hitam pada bagian mata, pakaian gothic, serba hitam dan rambut yang lurus kesamping.

Semakin berjalannya waktu, setiap individu menggunakan pakaian sebagai salah satu cara mengekpresikan diri mereka dengan bebas dan muncul gaya berpakaian baru yaitu genderless dan androgyne. Jika dilihat dari penjelasan di atas, cara berpakaian di Indonesia sangat terpengaruh dengan Barat dan tanpa disadari masyarakat Indonesia berpakaian tidak melihat apakah pakaian tersebut pakaian pria atau sebaliknya. Masuknya ritel besar seperti UNIQLO dan MORAL (desainer Indonesia berkonsep genderless) dapat dikatakan bahwa Indonesia mempunyai pasar untuk pakaian berkonsep genderless. Media sosial memiliki peranan penting dalam hal tren fashion di Indonesia, melalui media sosial masyarakat dapat mengakses tren fashion yang sedang hangat diperbincangkan. Tidak hanya brand luar saja yang menggunakan konsep genderless, tetapi brand lokal seperti MORAL berkonsep genderless sebagai identitasnya. MORAL sengaja meleburkan batasan gender dalam berpakaian untuk memudahkan siapa saja untuk dapat bebas mengekspresikan diri melalui gaya berpakaian yang cocok dengan identitas pemakainya.

Akses jejaring sosial yang mudah dilakukan untuk melihat perkembangan fashion adalah hal yang mudah di zaman sekarang. Pekerjaan seperti content creator adalah salah satu perkerjaan yang mengandalkan kemajuan teknologi, seperti Instagram. Content creator memiliki peran penting dalam perkembangan fashion di Indonesia, tepatnya di Jakarta yang adalah kota besar. Berbagai macam gaya berpakaian adalah salah satu cara setiap orang untuk mengekspresikan dirinya, seperti Wisnu Genu. la adalah seorang content creator pria dan juga fashion stylist yang memiliki gaya genderless, pakaian yang ia kenakan kebanyakan bersiluet maskulin dengan aksen feminin. Melihat gaya berpakaian dari Wisnu Genu dapat terlihat bahwa cara berpakaian di Indonesia khususnya di Jakarta sudah mulai bebas, meskipun masih ada batasan yang masih belum dapat diterima oleh masyarakat. Penampilan yang bersiluet maskulin lebih dapat diterima jika dibandingkan oleh siluet wanita yang dikenakan oleh pria. Hal tersebut dapat dilihat dari jenis pakaian yang dibuat oleh para desainer dan content creator yang memiliki konsep 
genderless, akan tetapi siluet yang digunakan adalah siluet pria dibandingkan siluet wanita.

\section{Androgyne Fashion di Indonesia}

Menurut Haldani, androgyne fashion sudah lama ada dibandingkan dengan keberadaan konsep berpakaian genderless [1]. Kebebasan berpakaian dan media sosial seperti Instagram membuat beberapa individu dengan penampilan genderless dan androgyne menjadi fashion icon di Indonesia, seperti content creator Jovi Adhiguna Hunter. Jovi Adhiguna Hunter adalah content creator yang mengakui dirinya adalah seorang androgyne. la menyatakan bahwa menyukai pakaian wanita tetapi tidak selalu memakainya setiap hari, seperti menggunakan blazer wanita tetapi menggunakan celana pria. Jovi Adhiguna Hunter adalah seorang pria yang memiliki fitur dari orientasi gender pria dan wanita, yang dapat dikategorikan dalam konsep androgyne. Tidak hanya content creator seperti Jovi tetapi model Indonesia seperti Darell Ferhostan juga memiliki image androgyne, ia memulai karirnya sebagai model pada tahun 2011. Sebagai model pendatang baru yang memiliki fisik kurus, tinggi, berambut panjang dan mempunyai fitur dari pria dan wanita menarik perhatian penyuka fashion dan menjadi salah satu model terkenal yang tampil dibanyak fashion show. Selain di Indonesia, Darell juga menjadi model freelance di berbagai negara seperti Australia, Thailand dan Paris.

\section{Preferensi}

Genderless fashion dan androgyne fashion adalah konsep berpakaian yang sering disamakan oleh masyarakat. Dilihat dari pernyataan-pernyataan para ahli dan karakteristik masing-masing konsep dapat dilihat bahwa genderless dan androgyne bukanlah hal yang sama. Secara sekilas genderless dan androgyne adalah dua hal yang sama, akan tetapi perbedaan terdapat pada cara menginterpretasikannya. Genderless fashion adalah suatu proses perancangan sebuah pakaian tanpa ada orientasi gender secara spesifik dan cara berekspresi setiap individu dalam berpakaian. Sedangkan androgyne fashion adalah suatu penampilan eksterior seseorang yang memiliki karakteristik kedua orientasi gender yaitu pria dan wanita.

Dengan penjelasan diatas dapat disimpulkan bahwa genderless lebih kepada proses sebuah perancangan dan androgyne adalah istilah yang digunakan untuk individu dengan fitur kedua orientasi gender yaitu pria dan wanita.

\section{METODE PENELITIAN}

Artikel ini akan membahas tentang pengertian genderless fashion dan apa yang membuat perbedaan antara genderless fashion dengan androgyne fashion dan mencari tahu preferensi masyarakat Indonesia akan genderless fashion dengan menggunakan pendekatan kualitatif dan kuantitatif (mixed method) berupa kajian pustaka melalui buku, jurnal dan penelitian terdahulu serta melakukan pembuatan kuesioner yang akan diberikan ke masyarakat yang bekerja di bidang fashion maupun tidak dengan responden usia dewasa awal. Kuesioner akan diberikan kepada masyarakat dengan umur kisaran 2128 tahun (dewasa awal) dan di Jakarta, karena merupakan kota metropolitan dengan perkembangan fashion yang cukup beragam dan pesat. Kuesioner ini akan berisikan pertanyaan untuk respoden berupan bagaimana pendapat mereka tentang genderless fashion, perbedaan genderless fashion dengan androgyne fashion serta gambar-gambar yang berkaitan dengan preferensi mereka atas genderless fashion. Kuesioner dapat diisi pada GoogleDocs dan akan disebar melalui media sosial seperti Instagram dan WhatsApp.

\section{PANDANGAN MASYARAKAT JAKARTA TERHADAP GENDERLESS FASHION}

\section{Pengumpulan Data}

Kuesioner ini bertujuan untuk mengetahui bagaimana pemahaman masyarakat terhadap genderless fashion dan bagaimana preferensinya. Kuesioner ini juga dibuat dan 
disebarkan secara daring melalui situs GoogleForm (http://docs.google.com/forms/) sehingga peneliti dapat mudah menyebarkan kuesioner kepada responden yang tinggal di beberapa daerah di Jakarta. Kuesioner dibagi menjadi empat bagian yaitu data responden, pengetahuan responden terhadap genderless fashion dan androgyne fashion, kepantasan pakaian terhadap pria dan wanita, dan juga preferensi masyarakat Jakarta terhadap genderless fashion.

\section{Hasil Survey}

Setelah kuesioner berhasil disebar dan dibagikan, peneliti membatasi jumlah responden sebanyak 63 orang yang pembagian analisisnya melalui orientasi gender, usia dan pekerjaan. Pembagian kategori berdasarkan orientasi gender, usia dan pekerjaan dilakukan untuk mengetahui karakter masing-masing kategori.

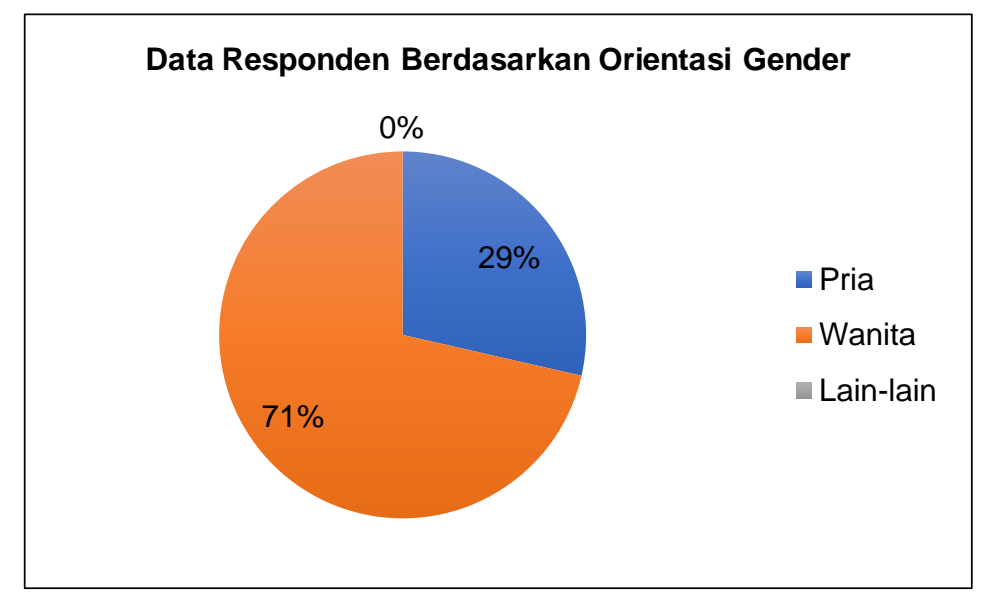

Gambar 1 Data responden (gender)

Pembagian kategori orientasi gender pria, wanita dan lain-lain dengan alasan untuk mencari tahu apakah ada perbedaan pendapat antara tiga orientasi gender tersebut. Responden pria sebanyak 18 orang dengan persentase $29 \%$, wanita sebanyak 45 orang dengan persentase $71 \%$ dan lain-lain sebanyak 0 orang dengan persentase $0 \%$. Pilihan lain-lain ditujukan kepada orientasi gender selain pria dan wanita seperti queer, yaitu seseorang yang menganggap dirinya bukanlah seorang pria dan wanita atau sebaliknya. Persentase wanita lebih dominan dikarenakan penyebaran kuesioner dilakukan melalui media sosial yang ruang lingkup pertemanan di dominasi oleh wanita dibandingkan pria.

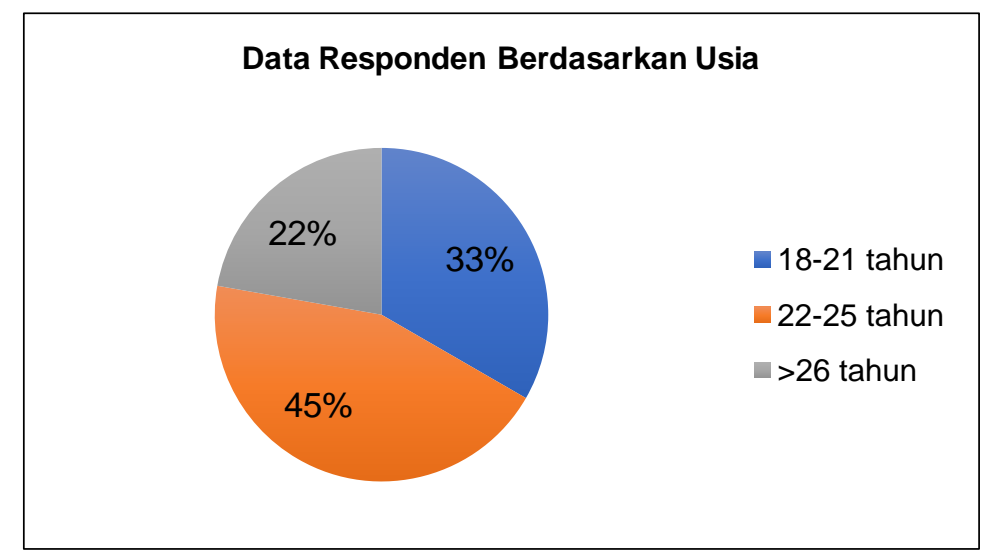

Gambar 2 Data responden (presentase data) 
Pembagian kategori usia dilakukan pada usia dewasa muda atau awal dengan penjelasan seperti berikut:

- Responden sebanyak 21 orang dengan persentase 33\% adalah responden dengan usia 18-21 tahun yang termasuk dalam usia dewasa muda atau awal.

- Responden sebanyak 28 orang dengan persentase $45 \%$ adaah responden dengan usia 22-25 tahun yang juga termasuk dalam usia dewasa awal tetapi lebih ke arah usia dewasa awal dengan kematangan yang lebih dalam hal berfikir logis dan terbuka akan hal baru.

- Responden sebanyak 14 orang dengan persentase $22 \%$ adalah responden dengan usia di atas 26 tahun.

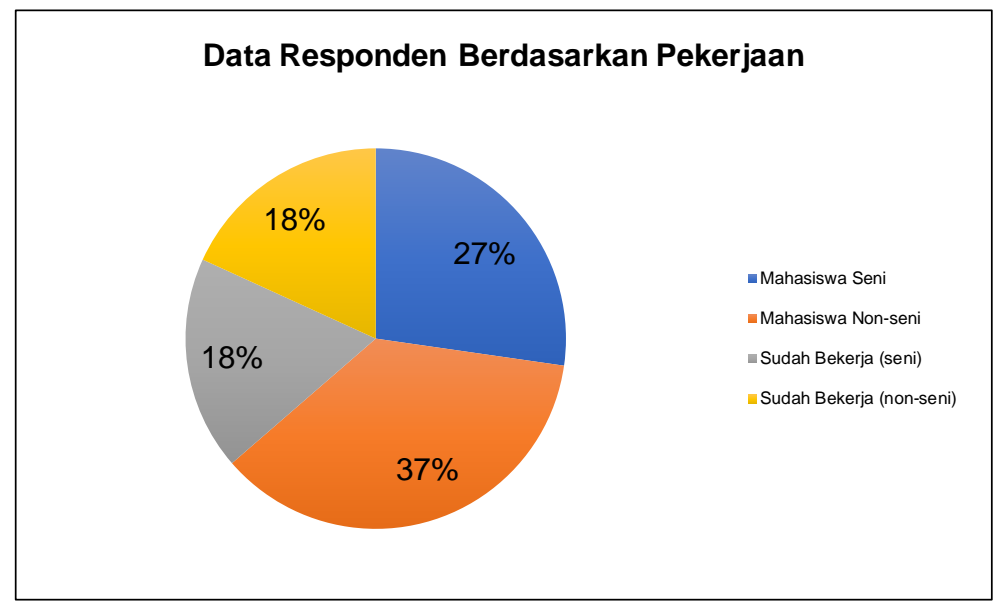

Gambar 3 Data responden (Pekerjaan)

Pembagian juga dilakukan atas pekerjaan dengan alasan apakah perbedaan pekerjaan pada bidang seni dan non-seni mempengaruhi pemikiran seseorang terhadap genderless fashion. Responden mahasiswa seni sebanyak 21 orang dengan persentase $27 \%$, responden mahasiswa non-seni sebanyak 28 orang dengan persentase $37 \%$, responden sudah bekerja di bidang seni sebanyak 14 orang dengan persentase $18 \%$ dan responden sudah bekerja di bidang non-seni sebanyak 14 orang dengan persentase $18 \%$.

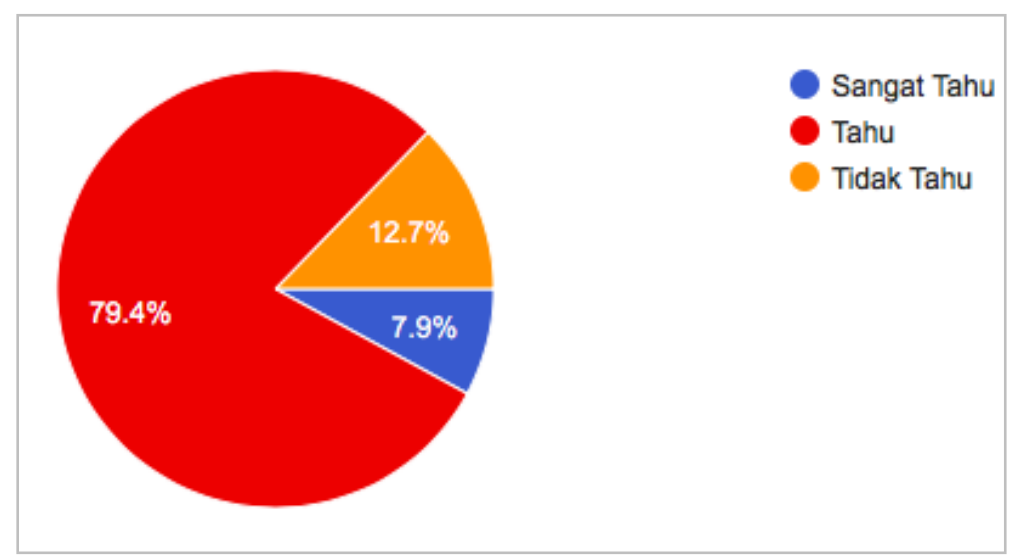

Gambar 4 Persentase pengetahuan responden terhadap genderless fashion.

Pertanyaan berikutnya adalah mengenai pengetahuan terhadap genderless fashion. Dari grafik diatas menunjukan bahwa secara keseluruhan responden sebanyak 50 orang dengan persentase $79.4 \%$ menjawab mengetahui apa itu genderless fashion, responden sebanyak 8 orang dengan persentase $12.7 \%$ menjawab tidak mengetahui apa itu genderless fashion dan responden sebanyak 5 orang dengan persentase $7.9 \%$ menjawab sangat mengetahui genderless fashion. Dari data diatas disimpulkan bahwa sebagian besar responden mengetahui apa itu genderless fashion. 


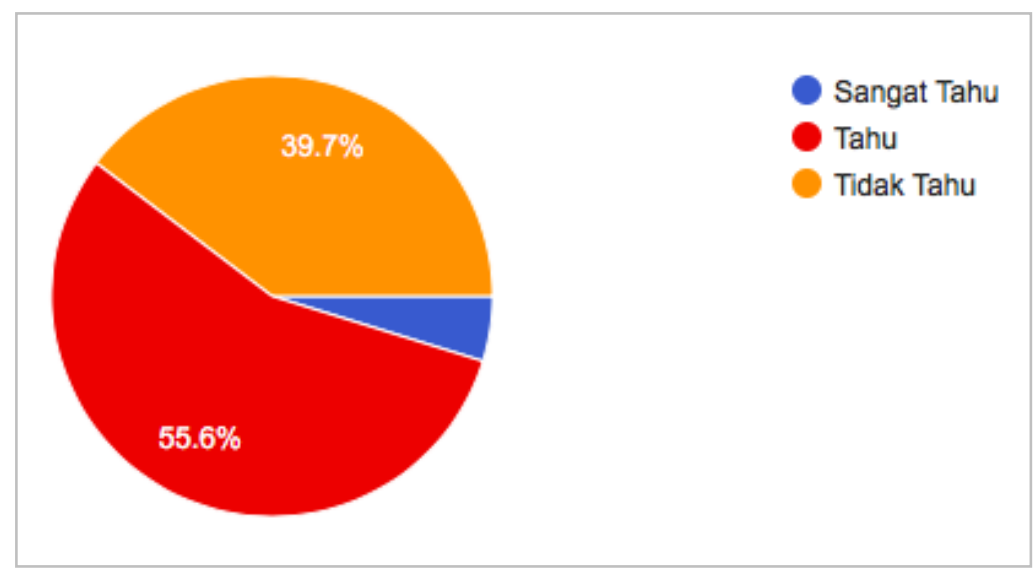

Gambar 5 Persentase pengetahuan responden terhadap androgyne fashion.

Pertanyaan berikutnya adalah mengenai pengetahuan responden terhadap androgyne fashion. Dari grafik di atas menunjukkan bahwa secara dominan sebanyak 35 orang dengan persentase 55.6\% menjawab mengetahui apa itu androgyne fashion, responden sebanyak 25 orang dengan persentase $39.7 \%$ menjawab tidak mengetahui apa itu androgyne fashion dan responden sebanyak 3 orang dengan persentase $4.8 \%$ menjawab sangat mengetahui androgyne fashion. Dari grafik di atas dapat disimpulkan bahwa sebagian besar responden menjawab mengetahui apa itu androgyne fashion.

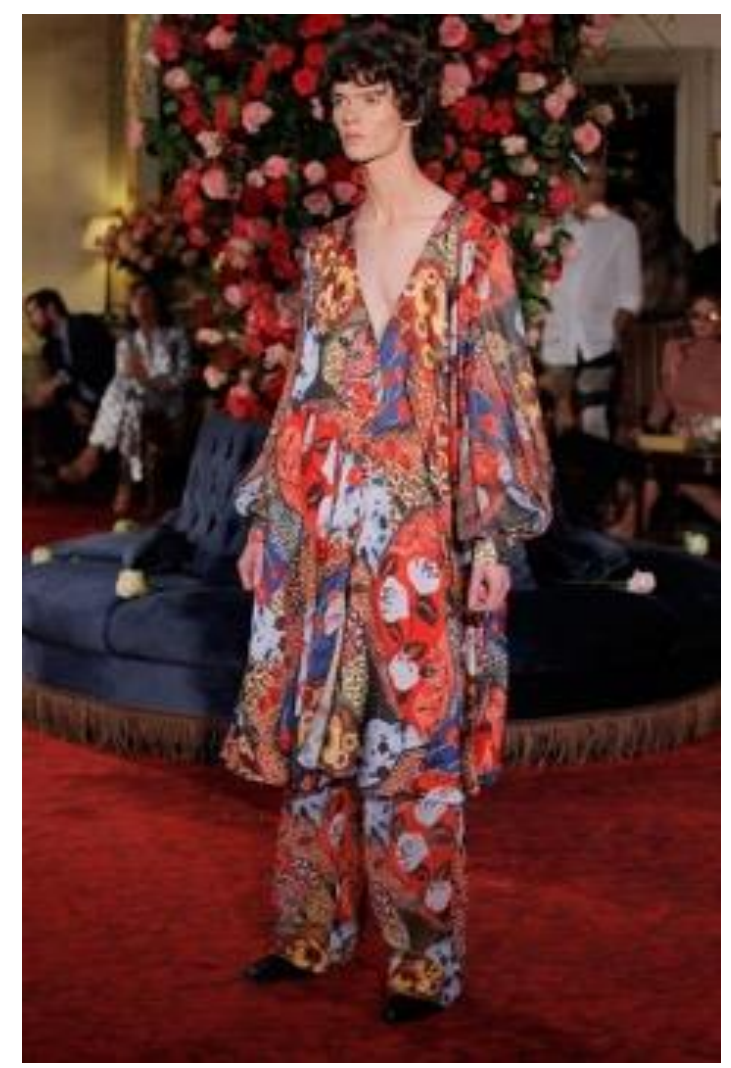

Gambar 6 Gambar pada kuesioner

Pertanyaan berikutnya adalah mengenai wajar atau tidaknya jika pria mengenakan pakaian tersebut. Berdasarkan grafik diatas menunjukkan bahwa secara keseluruhan responden sebanyak 40 orang dengan persentase $63.5 \%$ menjawab wajar jika pakaian tersebut dikenakan oleh pria dan 23 orang dengan persentase $36.5 \%$ menjawab tidak wajar. Dari data di atas dapat disimpulkan bahwa sebagian besar responden menjawab 
wajar jika pakaian tersebut dikenakan oleh pria. Pertanyaan berikutnya adalah mengenai wajar atau tidaknya jika wanita mengenakan pakaian tersebut. Dari grafik di atas 62 orang dengan persentase $100 \%$ menjawab wajar jika pakaian tersebut dikenakan oleh wanita.

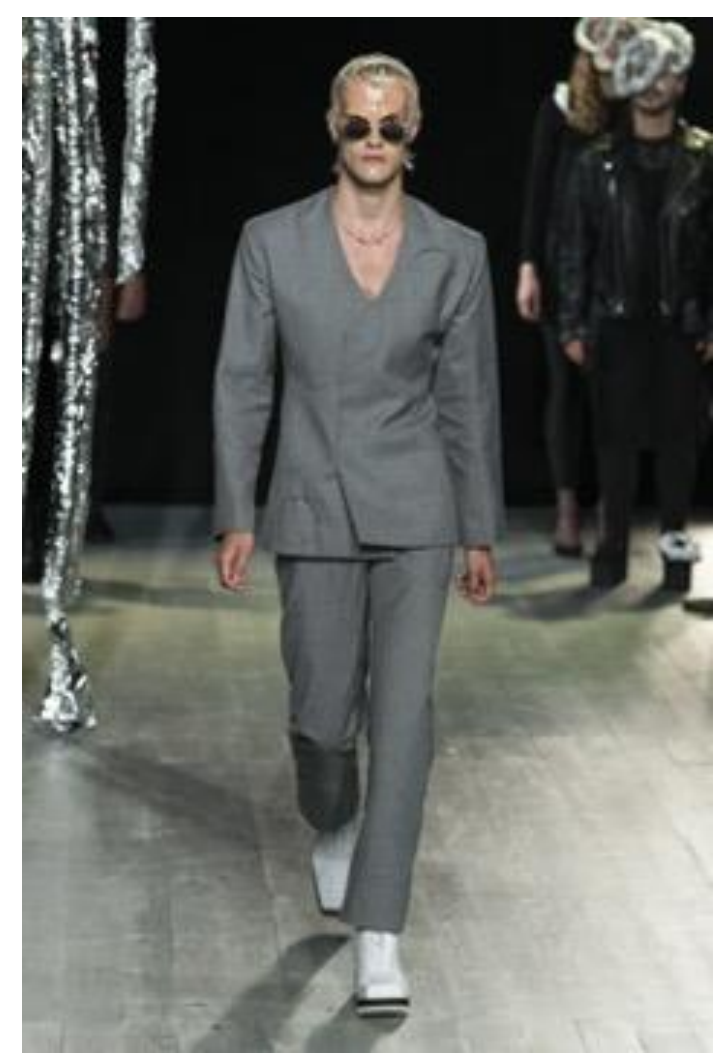

Gambar 7 Gambar pada kuesioner

Pertanyaan berikutnya adalah mengenai wajar atau tidaknya jika pria mengenakan pakaian tersebut. Secara keseluruhan responden menjawab wajar, sebanyak 62 orang dengan persentase $98.4 \%$ menjawab wajar jika pakaian tersebut dikenakan pria dan sebanyak 1 orang dengan persentase $1.6 \%$ menjawab tidak wajar. Dari data diatas dapat disimpulkan sebagian besar responden menjawab wajar jika pakaian tersebut dikenakan pria. Pertanyaan berikutnya adalah mengenai wajar atau tidaknya jika pria mengenakan pakaian tersebut. Dari grafik diatas menunjukkan bahwa secara keseluruhan sebagian besar responden menjawab wajar. Sebanyak 62 orang dengan persentase $98.4 \%$ menjawab wajar dan 1 orang dengan persentase $1.6 \%$ menjawab tidak wajar jika pakaian tersebut dikenakan wanita.

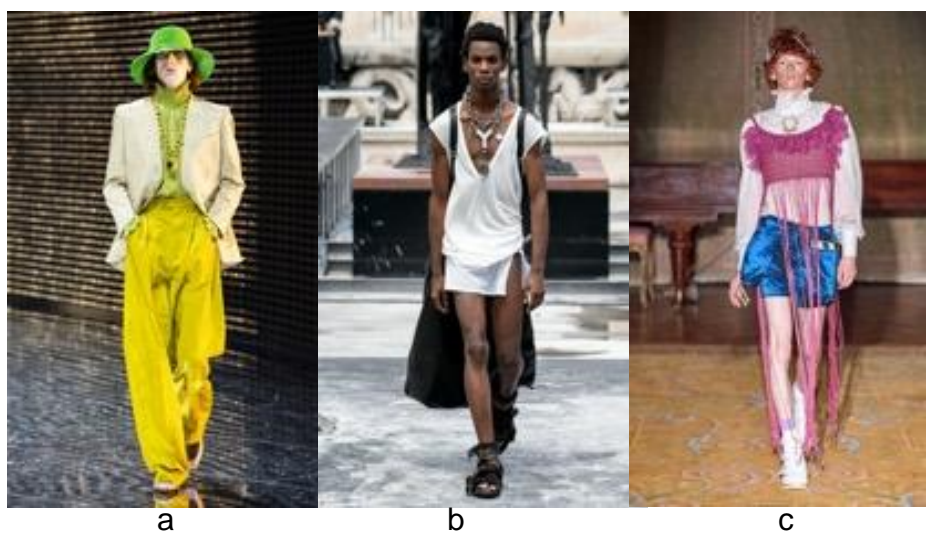

Gambar 8 Gambar pada kuesioner 
Pertanyaan selanjutnya mengenai preferensi responden terhadap pakaian genderless. Dari grafik di atas menunjukkan bahwa keseluruhan responden sebanyak 51 orang dengan persentase $83.6 \%$ memilih pakaian a untuk dikenakan, responden sebanyak 7 orang dengan persentase $11.5 \%$ memilih pakaian $b$ dan responden sebanyak 3 orang dengan persentase $4.9 \%$ memilih pakaian c untuk dikenakan.

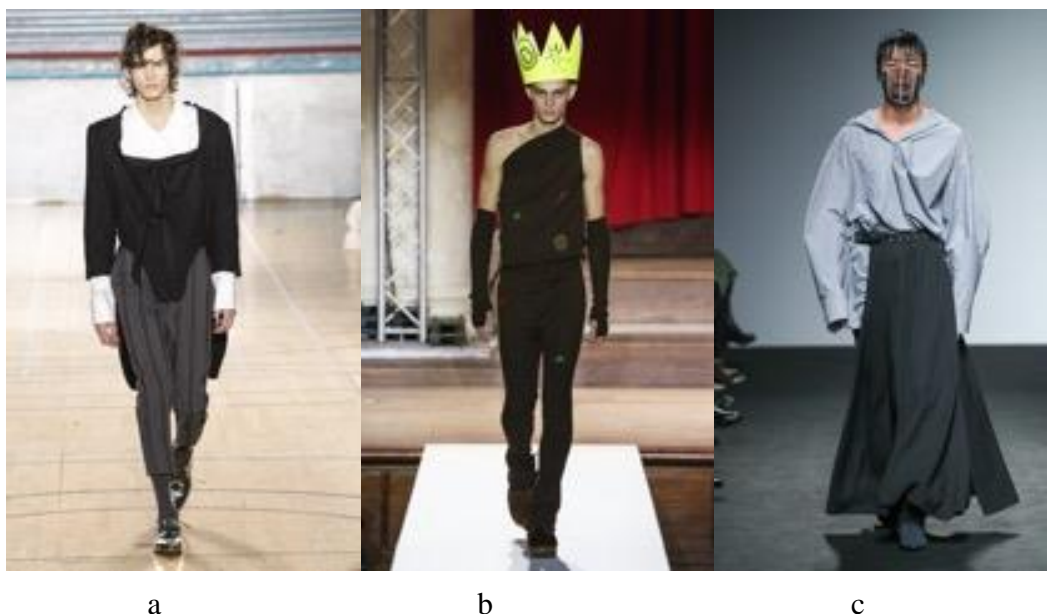

Gambar 9 Gambar pada kuesioner

Pertanyaan berikutnya adalah preferensi responden terhadap pakaian genderless, responden di minta untuk memilih pakaian genderless mana yang mereka pilih untuk acara formal. Pilihan responden cukup beragam, responden sebanyak 25 orang dengan persentase $40.3 \%$ memilih gambar c, responden sebanyak 24 orang dengan persentase $38.7 \%$ memilih gambar a dan responden sebanyak 13 orang dengan persentase $21 \%$ memilih gambar b untuk dikenakan pada acara formal.

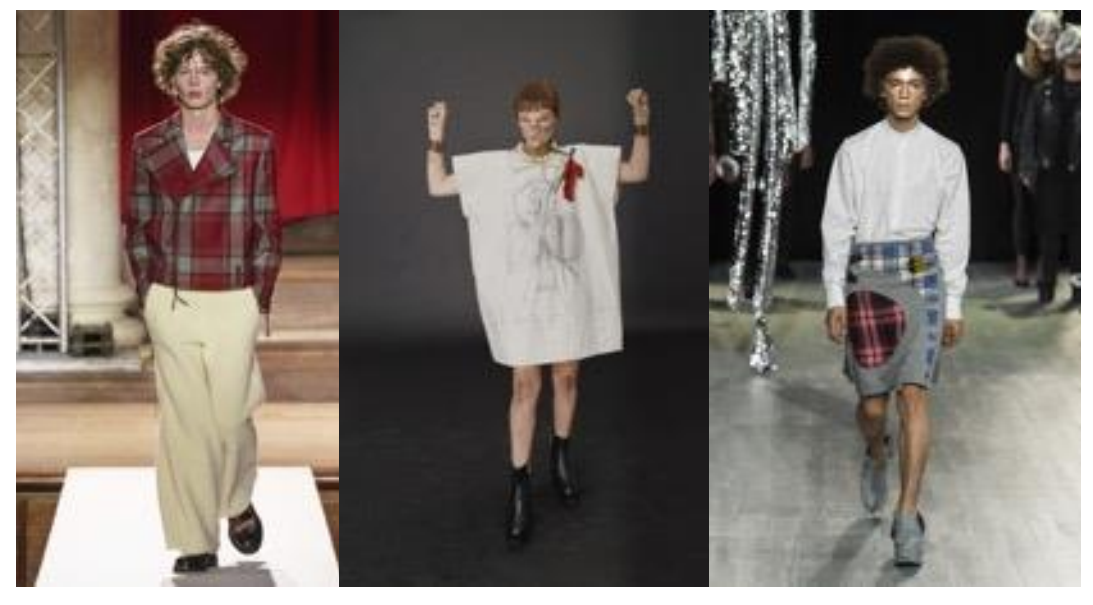

a

b

C

Gambar 10 Gambar pada kuesioner

Pertanyaan selanjutnya mengenai preferensi responden terhadap pakaian genderless untuk keseharian, responden di minta untuk memilih pakaian genderless mana yang mereka pilih untuk keseharian. Responden sebanyak 30 orang dengan persentase $48.4 \%$ memilih gambar c, responden sebanyak 23 orang dengan persentase $37.1 \%$ memilih gambar a dan responden sebanyak 9 orang dengan persentase $14.5 \%$ gambar b. 
Dari hasil survey responden dapat disimpulkan bahwa:

- Sebagian besar responden mengetahui pengertian genderless fashion dibandingkan dengan androgyne fashion.

- Sebagian besar responden memilih pakaian dengan siluet maskulin sebagai pakaian genderless dibandingkan pakaian dengan siluet feminin.

- Pakaian dengan siluet maskulin lebih wajar jika dikenakan oleh wanita dibandingkan dengan pakaian dengan siluet feminin dikenakan oleh pria.

- Responden lebih memilih pakaian dengan siluet maskulin, tertutup dan berwarna netral.

\section{KESIMPULAN}

Dari hasil analisis literature review, genderless fashion adalah suatu proses perancangan sebuah pakaian tanpa ada orientasi gender secara spesifik dan cara berekspresi individu dalam berpakaian. Berdasarkan sumber tersebut genderless fashion mempunyai konsep pakaian yang tidak menentukan gender pada saat didesain. Serta pembauran antara jenis kelamin pria dan wanita, bentuk kebebasan berekspresi personal dan tidak ada rasa khawatir untuk menjadi terlalu feminin atau terlalu maskulin. Perbedaan antara genderless fashion dengan androgyne fashion terletak pada karakteristik fisik seseorang, dimana konsep androgyne fashion digunakan untuk individu yang mempunyai karakteristik fitur pria dan wanita.

Dalam penelitian ini dilakukan penyebaran kuesioner untuk mengetahui preferensi masyarakat Jakarta terhadap genderless fashion. Menurut analisis data responden, sebagian besar mengetahui pengertian genderless fashion dan menganggap bahwa jika pakaian berbentuk rok adalah pakaian wanita. Pakaian yang mengandung unsur feminin seperti motif floral wajar jika dikenakan oleh pria, akan tetapi pada usia di atas 26 tahun berpendapat bahwa tidak wajar jika dikenakan oleh pria dan jika wanita mengenakan satu stel suits yang maskulin juga hal yang wajar. Dalam menganalisis preferensi masyarakat Jakarta lebih memilih siluet pakaian yang sering dilihat atau terbiasa dilihat seperti suits, berwarna netral, tidak terlalu feminin dan terlihat netral.

Kesimpulan yang didapat adalah masyarakat Jakarta dapat menerima adanya fenomena genderless fashion. Akan tetapi masih ada batasan yang belum dapat diterima, seperti pakaian yang terlalu feminin untuk dikenakan oleh pria. Pakaian seperti rok pendek, berwarna cerah, pakaian yang memiliki siluet yang sering ada pada pakaian wanita dan tidak ada unsur maskulin belum dapat diterima dan dikenakan oleh pria. Namun jika pakaian dengan warna cerah dan menggunakan siluet yang biasa digunakan oleh pria masih dapat diterima dan dikenakan oleh masyarakat.

\section{DAFTAR PUSTAKA}

[1]. Haldani A. 2000. Street Style Sebagai Fenomena Budaya dan Pengaruhnya di Indonesia. Thesis. Institut Teknologi Bandung;

[2]. Gligorovska K. 2011. Exploration of The Gender Myth via Fashion Media: Androgyny and Dandyism in Contemporary Fashion Magazines.Thesis. Stockholm University; [3]. Talha S. 2012. Cross Cultural Influences on Female Apparel Selection : A Comparison of Norway and Pakistan. Thesis. University of Agder;

[4]. Anindya A. 2016 Gender Fluid dan Identitas Androgini Dalam Media Sosial. Tingkap [Internet]. 12(2):107-18. Available from:

https://scholar.google.co.id/scholar?hl=id\&as_sdt=0\%2C5\&q= 